\title{
Functional response of Telenomus remus Nixon (Hymenoptera, Scelionidae) to Spodoptera frugiperda (J. E. Smith) (Lepidoptera, Noctuidae) eggs: effect of female age
}

\author{
Tatiana R. Carneiro', Odair A. Fernandes², Ivan Cruz $^{1} \&$ Regiane C. O. F. Bueno ${ }^{3}$
}

'EMBRAPA Milho e Sorgo, Caixa Postal 151,35701-970 Sete Lagoas-MG, Brasil. tatianacarneiro@hotmail.com; ivancruz@cnpms.embrapa.br

${ }^{2}$ UNESP-Universidade Estadual Paulista, Departamento de Fitossanidade, Via de Acesso Prof. Paulo Donato Castellane, km 5, 14884-900 Jaboticabal-SP, Brasil. oafernandes@fcav.unesp.br

${ }^{3}$ EMBRAPA Soja, Rodovia Carlos João Strass, Distrito de Warta, 86001-970 Londrina-PR, Brasil. regiane@cnpaf.embrapa.br

\begin{abstract}
Functional response of Telenomus remus Nixon (Hymenoptera, Scelionidae) to Spodoptera frugiperda (J. E. Smith) (Lepidoptera, Noctuidae) eggs: effect of female age. Functional response of 24-h and 48-h-old Telenomus remus adults was studied on Spodoptera frugiperda eggs. The study was carried out in climatic chamber regulated at $25 \pm 1{ }^{\circ} \mathrm{C}, 70 \pm 10 \% \mathrm{RH}$ and $12: 12 \mathrm{~h}(\mathrm{~L}$ : D). Females of T. remus were honey fed and individualized in glass vials along with 25, 50, 75, 100, 150, 200, 250 or 300 eggs of $S$. frugiperda for $24 \mathrm{~h}$. Complete randomized design with ten replications was adopted. The parameters evaluated to construct the functional response curve were daily average parasitism, searching rate and oviposition time. It was observed that the higher the egg density, the higher the parasitism for 24-h and 48-h-old females although there was a tendency of parasitism stabilization at 150-egg density. The results showed a type II functional response curve for both 24-h and 48-h-old female.
\end{abstract}

KEYWORDS. Biological control; fall armyworm; oviposition time; parasitoid; search rate.

RESUMO. Resposta funcional de Telenomus remus Nixon (Hymenoptera, Scelionidae) sobre ovos de Spodoptera frugiperda (J. E. Smith) (Lepidoptera, Noctuidae): efeito da idade da fêmea. A resposta funcional de fêmeas de Telenomus remus com 24 h e 48 $\mathrm{h}$ de idade foi observada em ovos de Spodoptera frugiperda. O experimento foi conduzido em câmara climatizada regulada a $25 \pm$ $1{ }^{\circ} \mathrm{C}, 70 \pm 10 \%$ UR e fotofase de $12 \mathrm{~h}$. As fêmeas de T. remus foram alimentadas com mel e mantidas individualmente por $24 \mathrm{~h}$ em tubos de vidro que continham 25, 50, 75, 100, 150, 200, 250 ou 300 ovos de $S$. frugiperda. Foi adotado o delineamento experimental inteiramente casualizado com 10 repetições. Os parâmetros avaliados para a construção da curva de resposta funcional foram o parasitismo médio diário, a taxa de busca e o tempo de oviposição. Foi observado que com o aumento da densidade de ovos também cresce o parasitismo em fêmeas com 24 h e 48 h de idade e que há uma tendência de estabilização do parasitismo na densidade de 150 ovos/fêmea. Os resultados mostraram uma curva de resposta funcional do tipo II para fêmeas de T. remus com 24 h e 48 h de idade.

PALAVRAS-CHAVE. Controle biológico; lagarta-do-cartucho; parasitóide; tempo de oviposição; tempo de busca.

Telenomus remus Nixon is an exclusive parasitoid of lepidopterous pests and several studies have been conducted worldwide to evaluate the efficiency of this natural enemy on Spodoptera frugiperda (J. E. Smith) eggs (Joshi et al. 1976; Gupta \& Pawar 1985; Cruz \& Figueiredo 1994; Morales et al. 2000). The parasitism of T. remus on S. frugiperda, S. latifascia (Walker), S. exigua (Hübner) and S. eridania (Cramer) under laboratory conditions varied from 80 to $100 \%$, according to Wojcik et al. (1976). In Venezuela (Hernández et al. 1989) and other Central American countries (González \& Zocco 1996; Cave \& Acosta 1999; Cave 2000), studies have shown that $T$. remus can cause up to $90 \%$ of parasitism in $S$. frugiperda eggs, releasing 5,000 to 8,000 parasitoids/ha. Also in Venezuela, Ferrer (2001) reports the use of T. remus combined with Trichogramma pretiosum Riley (Hymenoptera, Trichogrammatidae) to control fall armyworm infestations in 1,600-ha maize field. This program caused $34 \%$ reduction in insecticide use.

In Brazil, the insect was first introduced in the mid 1980's aiming at evaluating its efficacy to control fall armyworm in a classical biological control program. Despite that, very few studies have been conducted to evaluate the performance of T. remus under local conditions. However, as Cave \& Gaylor (1989) highlighted, it is very important to study Telenomus species because they are parasitoids with great biological control potential.

Studies on the interaction of this natural enemy and its host, as the functional response, for instance, can be helpful in integrated pest management programs, once this facilitates to determine predation/parasitism dynamics of a natural enemy. Response to prey density can affect survivorship and fecundity and, therefore, the intrinsic rate of increase as stated by Hassel (1978). As this parasitoid has been mass reared on fall armyworm eggs for many years, the evaluation of functional response is necessary prior to any release.

The study carried out by Morales et al. (2001) in Venezuela evaluated only the functional response of 24hour-old females and adopted polynomial regression to express it which is not appropriate to model the relationship between predation/parasitism rate and prey/host densities. 
All functional response curves proposed by Holling (1959) stabilize at a certain predation/parasitism rate level, which is related to the maximum number of preys/hosts attacked per time unit. However, polynomial regression does not allow the determination of such a level. Thus, although it is easy to calculate, it is not helpful.

Several factors can affect the development of natural enemies. Among those factors, the most important is the density and the behavioral characteristics of the predator/ parasitoid and prey/host (Holling 1961). When such factors are evaluated through mathematic models as suggested by Holling (1959), three different types of functional responses can be obtained, represented by discrete curves (Van Alphen \& Jervis 1996).

The type II curve is more often related to systems involving arthropods, including predator and parasitoid insects (Cave \& Gaylor 1989; Garcia 1991), although type III curve is often observed for egg parasitoids (Wang \& Ferro 1998; ReayJones et al. 2006). The main characteristic of the type II functional response is a gradual increase of consumed preys, due to their greater availability, up to a density in which there is stabilization in the consumption rate (Hassel 1978; Hassel et al. 1997). Type II curve is a hyperbola that differentiates from the other types by presenting a gradual increase in the number of the eaten preys (Van Alphen \& Jervis 1996) or parasitized hosts.

Below is the disk equation as suggested by Holling:

$$
\mathrm{Na}=(\mathrm{a} * \mathrm{Tt} * \mathrm{~N}) /(1+\mathrm{a} * \mathrm{Th} * \mathrm{~N})(1)
$$

In which: $\mathrm{Na}=$ number of eaten preys/parasitized hosts, a $=$ predator/parasitoid searching rate, $\mathrm{Tt}=$ total exposure time, $\mathrm{N}=$ prey/host density, $\mathrm{Th}=$ handling/oviposition time.

The ability of predator females to search and attack hosts is a determinant factor to define its population size in a given area, while changes in foraging behavior can be responsible for success or failure of biological control programs (Lewis et al. 1990). Therefore, since functional responses can represent key factors in selecting natural enemies for a biological control program (Lester \& Harmsen 2002), the present study aimed at demonstrating, by using the curves obtained from the Holling equation, how the $T$. remus egg parasitoid responds to the increase in the density of the eggs of $S$. frugiperda. Moreover, it was intended to demonstrate the effect of parasitoids' age in its functional response and, therefore, the feasibility of releasing older females in biological control programs.

\section{MATERIAL \& METHODS}

Daily Average Parasitism. The experiment was conducted with the following $S$. frugiperda egg densities: $25,50,75$, $100,150,200,250$ and 300 eggs. In order to obtain such densities eggs were counted multiplying the number of eggs in the superior layer by the number of deposition layers of each egg mass. The number of eggs on the edges was added to the total (Beserra \& Parra 2005).

Ten parasitoid females were used for each egg density. The females were placed in glass tubes $(8 \mathrm{~cm}$ height $\times 2 \mathrm{~cm}$ diameter) individually, and oviposition was allowed for 24 hours. The procedure was performed with 24 and 48 hour-old
T. remus females without previous egg laying experience. All females were fed with small drops of honey placed on the internal walls of the tube.

During the experiment, the tubes containing females and S. frugiperda eggs were kept in a controlled environment chamber at $25 \pm 1{ }^{\circ} \mathrm{C}, \mathrm{RH} 70 \pm 10 \%$ and $12 \mathrm{~h}$ of photophase. Newly hatched larvae were counted and withdrawn from the tubes with a brush so they would not be able to feed on parasitized eggs. Such observations were performed in the first four days after oviposition at 12-hour intervals. Parasitoids that emerged from the remaining eggs were counted after death, and sexed under stereoscopic microscope (Zeiss Stemi V6, Germany).

Oviposition time and searching rate. To determine oviposition time, $20 \mathrm{~T}$. remus females from each of the treatments (24 and 48 hour-old individuals) were placed in Petri dishes ( $1 \times 8 \mathrm{~cm}$ diameter) individually and exposed to approximately $100 \mathrm{~S}$. frugiperda eggs. The time females were in contact with an egg was measured and all parasitoid activities were videotaped for time checking. During observation, the females were kept in a room with controlled temperature and humidity $\left(25 \pm 1^{\circ} \mathrm{C}, \mathrm{RH} 70 \pm 10 \%\right)$.

The searching rate was calculated as described by Cave \& Gaylor (1989) and Morales et al. (2001), in which the number of parasitized eggs is divided by the total number of eggs exposed to the parasitoid.

Statistical Analysis. The experiment was arranged in completely randomized design and data were submitted to ANOVA. Means were compared by the Tukey test $(\mathrm{P} \leq 0.05)$. The Holling equation (1) was used to build the functional response curves. However, a model which incorporates depletion (host depletion in our case) was also used to analyze the functions according to Juliano (2001). This analysis was performed using PROC CATMOD (SAS Institute 2004).

\section{RESULTS}

Oviposition Time, Daily Mean Parasitism and Searching Rate. T. remus females did not show significant difference on oviposition time regardless age $(\mathrm{df}=2 ; \mathrm{F}=12.07 ; \mathrm{P} 0.05)$. Twenty-four-hour-old females spent $40.6 \mathrm{sec} / \mathrm{egg}(36.0-42.0$ $\mathrm{s} / \mathrm{egg})$, whereas 48 -h-old females spent $41.3 \mathrm{sec}$./egg (34.0 $45.0 \mathrm{~s} / \mathrm{egg}$ ), on average.

The mean number of eggs parasitized by T. remus females increased with higher egg host densities, and stabilized at and beyond the density of 150 eggs (Table I). It can be observed that the age was not a major factor influencing the searching rates as the egg density. T. remus showed a decrease in the searching rates beyond the density of 150 eggs (Table I).

Sex Ratio. There was an increase tendency towards females in the progeny of $T$. remus as the age of female parasitoids increased (Table II), indicating that female age affects the sex ratio in the progeny. However, there is no influence of host density on the proportion of males and females in the progeny.

Functional Response. The results for 24-h and 48-h-old $T$. remus females allowed the adjustment of a Type II and Type 

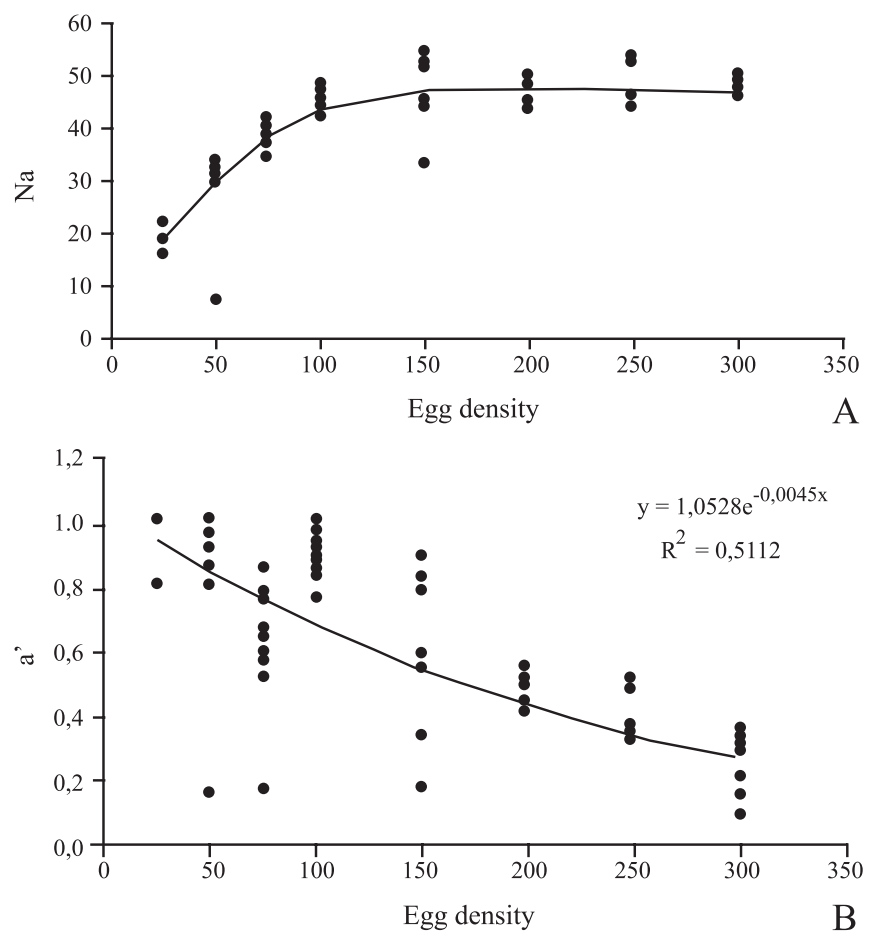

Fig. 1. Functional response of 24-h T. remus females on S. frugiperda eggs. $\mathrm{Na}=$ number of parasitized eggs/day [A]. Proportion of parasitized eggs/ available eggs (a') and egg density [B].

III functional responses, respectively, as suggested by Holling (1959). Despite the type, the stabilization of parasitism rate became evident at densities of 150 eggs and higher (Figs. 1 and 2).

\section{DISCUSSION}

The average oviposition time from several species of Telenomus, including $T$. remus is about $43 \mathrm{~s}$ (Cave et al. 1987), which is very close to the time found in the present study $(40,6-41,8$ s). Not many experiments have studied T. remus oviposition time, but Schwartz \& Gerling (1974) conducted a study to evaluate the oviposition time of 24hour-old females of that species using Spodoptera litorallis (Boisduval) (Lepidoptera, Noctuidae) eggs as host. These authors reported a mean time of $37 \mathrm{~s} / \mathrm{egg}$, which is close to the results observed even though a different host was used. Host recognition and handling is the key for successful parasitism, especially in host-specific parasitoids (Cave et al. 1987). The manner females handle host eggs and the time they take are directly related to the number of parasitized eggs. They represent the most important factors in functional response (Tillmam 1996).

The increased parasitism with higher egg host densities was also observed by Morales et al. (2001) studying T. remus 24-hour-old females, although these authors reported lower parasitism and searching rates at lower densities.

The age was not a major factor influencing the searching rates as the egg density was. This was explained by Rogers (1972), who noticed that the higher the host availability, the lower the searching rate of parasitoids, especially those which massively attack eggs, as $T$. remus.

According to Holling (1961), the host exposition time to the parasitoid, the oviposition time and the searching rate influence the functional response and these are essential parameters in behavior analysis. Therefore, these parameters should be obtained to enhance the information on a natural enemy's behavior and increase its efficacy (Fernandez-Arhex $\&$ Corley 2003), although functional response should not be taken into account alone to determine a potential species to be used in biological control programs (Lester \& Harmsen 2002; Fernandez-Arhex \& Corley 2003).

Insects belonging to the family Scelionidae usually attack hosts that deposit eggs masses and the progeny of these species presents a predominance of females (Gauld \& Bolton 1988). Besides, the sex ratio depends on the searching capacity of the females and its energy reserves (Rogers 1972).

Morales et al. (2000) demonstrated that 24-hour-old $T$. remus females exposed to $S$. frugiperda eggs produce 1 male for each 5.4 females and this ratio changes with parasitoid age. That is because females with up to $48 \mathrm{~h}$ of age produce 1 male for each 7.2 females, with an increase in the number of males starting from the third day ( $72 \mathrm{~h}$ of age). The same has been demonstrated by Schwartz \& Gerling (1974) studying biological aspects of $T$. remus on S. litura, who verified that 48-hour old $T$. remus females produce more females.

It would be therefore advisable that $T$. remus is kept in laboratory for at least $48 \mathrm{~h}$ after hatching before releasing parasitoids, so a higher number of females would be produced in the next generation. However, it must be considered that
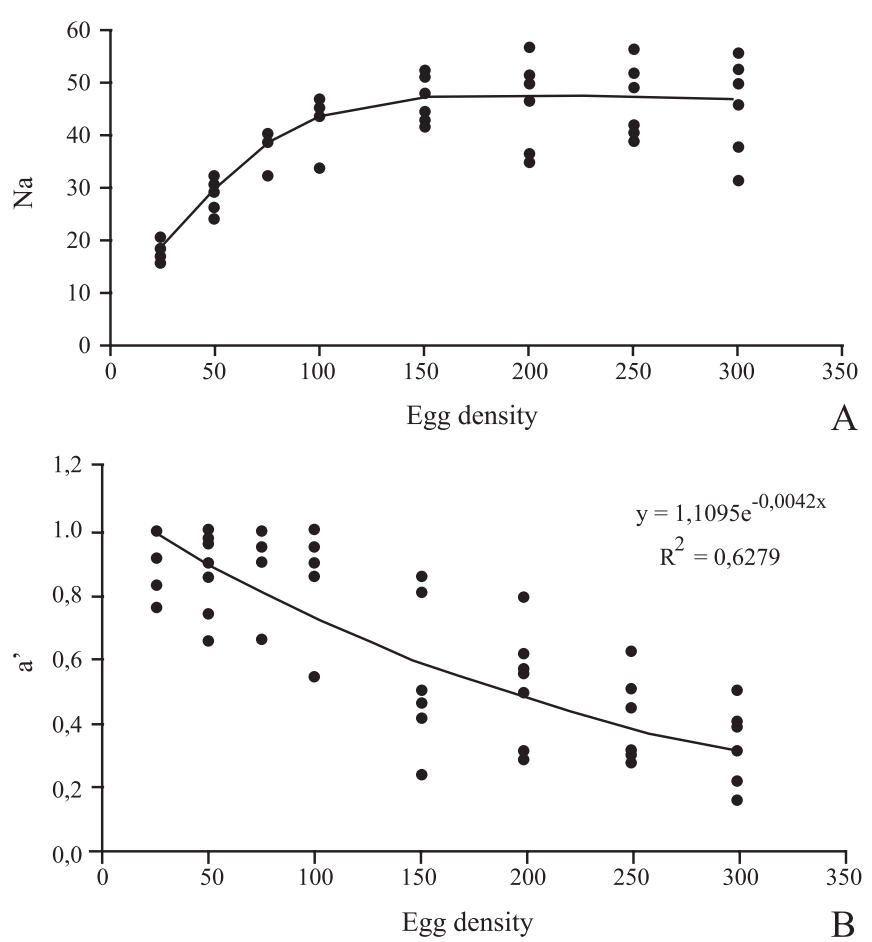

Fig. 2. A. Functional response of 48-h T. remus females on S. frugiperda eggs. $\mathrm{Na}=$ number of parasitized eggs/day [A]. Proportion of parasitized eggs/available eggs (a') and egg density [B]. 
Table I. Daily mean parasitism and searching rate $( \pm \mathrm{SE})$ of $T$. remus females at different $S$. frugiperda egg densities.

\begin{tabular}{|c|c|c|c|c|}
\hline \multicolumn{3}{|c|}{ Parasitism (eggs/day) } & \multicolumn{2}{|c|}{$\begin{array}{c}\text { Search rate } \\
\text { (parasitized eggs/ eggs) }\end{array}$} \\
\hline $\begin{array}{l}\text { Egg } \\
\text { density }\end{array}$ & $\begin{array}{l}\text { 24h-old } \\
\text { females }\end{array}$ & $\begin{array}{l}\text { 48h-old } \\
\text { females }\end{array}$ & $\begin{array}{l}\text { 24h-old } \\
\text { females }\end{array}$ & $\begin{array}{l}\text { 48h-old } \\
\text { females }\end{array}$ \\
\hline 25 & $24.0 \pm 0.67 \mathrm{a}$ & $23.2 \pm 1.20 \mathrm{a}$ & $0.96 \pm 0.03 \mathrm{a}$ & $0.93 \pm 0.05 a$ \\
\hline 50 & $43.5 \pm 4.10 \mathrm{a}$ & $43.7 \pm 2.50 \mathrm{a}$ & $0.87 \pm 0.08 \mathrm{a}$ & $0.87 \pm 0.05 \mathrm{a}$ \\
\hline 75 & $62.6 \pm 2.79 \mathrm{a}$ & $68.9 \pm 3.36 \mathrm{a}$ & $0.84 \pm 0.04 \mathrm{a}$ & $0.92 \pm 0.04 \mathrm{a}$ \\
\hline 100 & $90.1 \pm 2.45 \mathrm{a}$ & $86.7 \pm 6.82 \mathrm{a}$ & $0.90 \pm 0.02 \mathrm{a}$ & $0.87 \pm 0.07 \mathrm{a}$ \\
\hline 150 & $97.3 \pm 9.03 \mathrm{a}$ & $101.5 \pm 8.43 \mathrm{a}$ & $0.68 \pm 0.06 \mathrm{a}$ & $0.68 \pm 0.06 \mathrm{a}$ \\
\hline 200 & $96.6 \pm 2.84 \mathrm{a}$ & $037+1340 \mathrm{a}$ & $0.52 \pm 0.10 \mathrm{a}$ & $0.52 \pm 0.10 \mathrm{a}$ \\
\hline 250 & $96.7 \pm 5.95 \mathrm{a}$ & $103.0 \pm 14.20 \mathrm{a}$ & $0.41 \pm 0.06 \mathrm{a}$ & $0.41 \pm 0.06 \mathrm{a}$ \\
\hline 300 & $95.9 \pm 1.94 \mathrm{a}$ & $100.0 \pm 15.50 \mathrm{a}$ & $0.33 \pm 0.05 \mathrm{a}$ & $0.33 \pm 0.05 \mathrm{a}$ \\
\hline
\end{tabular}

Means followed by the same letter (row) are not significantly different for the same characteristic according to Tukey test $(\mathrm{P} \leq 0.05)$.

older adults would be released, and studies should be carried out to evaluate the influence of $T$. remus age on its field efficiency as a biological control agent.

Morales et al. (2001) also demonstrated that T. remus has a parasitism stabilization tendency at densities of 150 host eggs and higher. However, this stabilization was not so evident and authors have not demonstrated the Type II functional response through Holling's equation or any other more accurate method, but using polynomial regression analysis. The method used by the authors does not consider oviposition times and sex ratio, and uses absolute parasitism numbers. Therefore it does not characterize the functional response of the parasitoid, but solely the daily mean parasitism (Fan \& Petitt 1994; Tillmam 1996).

The tendency shown in the present study supports the observations of Holling $(1959,1961)$, who suggested the use of functional response studies as tools for better understanding predator-prey dynamics and not as parasitism capacity indices. The stabilization at the 150-egg density is confirmed in spite of the changes in $S$. frugiperda egg densities and time for oviposition, because according to Holling (1961) parasitoids are less attracted for oviposition under high host densities and this may reflect in functional response curves.

From the analysis of our results it can be concluded that 24-h and 48-h-old T. remus females have effective parasitism at low host densities and are able to continue oviposition when there is high $S$. frugiperda egg density. According to Huffaker \& Messenger (1976), these properties are ideal for an efficient natural enemy in biological control programs. Also, parasitoids are more commonly associated to type II functional response than to type III. However, we noticed that the age of an insect can interfere in such aspect. Therefore, this affects the rate of parasitism under low range of host densities; although this might not be of practical importance for biological control (Mills \& Lacan 2004).

The study of basic aspects of parasitoid-host interaction, as the functional response, searching rates and handling time has major importance, since it can contribute to studies on the impact of T. remus on S. frugiperda population dynamics. Moreover, in biological control programs that may use
Table II. Sex ratio ( \pm SE) of $T$. remus progeny at different $S$. frugiperda egg densities.

\begin{tabular}{ccc}
\hline Egg density & 24h-old females & 48h-old females \\
\hline 25 & $0.56 \pm 0.06 \mathrm{Ab}$ & $0.71 \pm 0.11 \mathrm{Aa}$ \\
50 & $0.69 \pm 0.09 \mathrm{Ab}$ & $0.86 \pm 0.02 \mathrm{Aa}$ \\
75 & $0.61 \pm 0.08 \mathrm{Ab}$ & $0.73 \pm 0.09 \mathrm{Aa}$ \\
100 & $0.61 \pm 0.07 \mathrm{Ab}$ & $0.78 \pm 0.11 \mathrm{Aa}$ \\
150 & $0.51 \pm 0.05 \mathrm{Ab}$ & $0.83 \pm 0.12 \mathrm{Aa}$ \\
200 & $0.64 \pm 0.07 \mathrm{Ab}$ & $0.83 \pm 0.03 \mathrm{Aa}$ \\
250 & $0.62 \pm 0.06 \mathrm{Ab}$ & $0.76 \pm 0.11 \mathrm{Aa}$ \\
300 & $0.58 \pm 0.06 \mathrm{Ab}$ & $0.85 \pm 0.14 \mathrm{Aa}$ \\
\hline
\end{tabular}

$\overline{\text { Means followed by the same capital letter (columns) or small letter (row) are }}$ not significantly different according to Tukey test $(\mathrm{P} \leq 0.05)$.

this natural enemy in the future, our data will be useful in calculating at which pest density the parasitoid should be released and which is the behavior of T. remus under host population changes.

Acknowledgement. The authors thank D. Gerling (Tel Aviv University, Israel) for helpful comments on the manuscript. Assistanship to T.R. Carneiro was provided by Coordenação de Aperfeiçoamento de Pessoal de Nível Superior (CAPES).

\section{REFERENCES}

Beserra, E. B. \& J. R. P. Parra. 2005. Impact of the number of Spodoptera frugiperda egg layers on parasitism by Trichogramma atopovirilia. Scientia Agricola 62: 190-193.

Cave, R. D. 2000. Biology, ecology and use in pest management of Telenomus remus. Biocontrol News and Information 21: 21-26.

Cave, R. D. \& M. J. Gaylor. 1989. Functional Response of Telenomus reynoldsi (Hym: Scelionidae) at five constant temperatures and in an artificial plant arena. Entomophaga 34: 3-10.

Cave, R. D. \& N. M. Acosta. 1999. Telenomus remus Nixon: un parasitoide en el control biológico del gusano cogollero, Spodoptera frugiperda (Smith). Ceiba 40: 215-227.

Cave, R. D.; M. J. Gaylor \& J. T. Bradley. 1987. Host handling and recognition by Telenomus reynoldsi (Hym.: Scelionidae), an egg parasitoid of Geocoris spp. (Heteroptera: Lygaeidae). Annals of Entomological Society of America 80: 217-223.

Cruz, I. \& M. L. C. Figueiredo. 1994. Estudos preliminares do parasitóide Telenomus sp. Nixon sobre ovos de Spodoptera frugiperda. Relatório Téenico Anual do Centro Nacional de Pesquisa de Milho e Sorgo 1992-1993. Sete Lagoas 6: 104-105.

Fan, Y. \& F. L. Petitt. 1994. Parameter Estimation of the Functional Response. Environmental Entomology 23: 785-794.

Fernandez-Arhex, V. \& J. C. Corley. 2003. The functional response of parasitoids and its implications for biological control. Biocontrol Science and Technology 13: 403-413.

Ferrer, F. 2001. Biological control of agricultural insect pests in Venezuela; advances, achievements, and future perspectives. Biocontrol News and Information 22: 67-74.

Gauld, I. \& B. Bolton. 1988. The Hymenoptera. Oxford University Press, $332 \mathrm{p}$.

Garcia, M. A. 1991. Ecologia nutricional de parasitóides e predadores terrestres, p. 289-305. In: J. R. P. Parra \& A. R. Panizzi (eds.). Ecologia nutricional de insetos e suas implicações no manejo de pragas. Brasília, Manole, $359 \mathrm{p}$.

González, C. E. \& J. L. Zocco. 1996. Control integrado de Spodoptera frugiperda (Smith) utilizando Telenomus remus (Nixon) em Zea mays L. Revista de Investigación Agrícola-DANAC 1: 201-219.

Gupta, M. \& A. D. Pawar. 1985. Multiplication of Telenomus remus Nixon on Spodoptera litura (Fabricius) reared on artificial diet. Journal of Advanced Zoology 6: 13-17. 
Hassel M. P. 1978. The dynamic of arthropod predator-prey systems. Princeton, Princeton University Press, $237 \mathrm{p}$.

Hassel, M. P.; J. H. Lawton \& J. R. Beddington. 1997. Sigmoid functional responses by invertebrate predator and parasitoids. Journal of Animal Ecology 46: 249-262.

Hernández, D.; F. Ferrer \& B. Linares. 1989. Introducción de Telenomus remus Nixon (Hym.: Scelionidae) para controlar Spodoptera frugiperda (Lep.: Noctuidae) en Yaritagua, Venezuela. Agronomia Tropical 39: 199-205.

Holling C. S. 1959. Some characteristics of simple types of predation and parasitism. Canadian Entomologist 91: 385-398.

Holling C. S. 1961. Principles of insect predation. Annual Review of Entomology 6: 163-182.

Huffaker, C. B. \& P. S. Messenger. 1976. Theory and practice of biological control. New York, Academic Press, 788 p.

Joshi, B. G.; G. Ramaprasad; S. Sitaramaiah \& C. V. V. Sathyanarayana. 1976. Some observations on Telenomus remus Nixon, an egg parasitoid of the tobacco caterpillar, Spodoptera litura (F.). Tobacco Research 2: $17-20$.

Juliano, S. A. 2001. Nonlinear curve fitting: predation and functional response curves, p.159-182. In: Scheiner, S. M. \& J. Gurevitch (eds.). Design and analysis of ecological experiments, $2^{\text {nd }}$. ed., New York, Chapman and Hall, p. 373.

Lester, P. J. \& R. Harmsen. 2002. Functional and numerical responses do not always indicate the most effective predator for biological control: an analysis of two predators in a two-prey system. Journal of Applied Ecolology 39: 455-468.

Lewis, W. J.; L. E. M. Vet; J. H. Tumlinson; J. C. Van Lenteren \& D. R. Papaj. 1990. Variations in parasitoid foraging: essential element of a sound biological control theory. Environmental Entomology 19: 1183-1193.

Mills, N. J. \& I . Lacan. 2004. Ratio dependence in the functional response of insect parasitoids: evidence from Trichogramma minutum foraging for eggs in small host patches. Ecological Entomology 29: 208-216.
Morales, J.; J. S. Gallardo; C. Vásquez \& Y. Ríos. 2000. Patrón de emergencia, longevidad, parasitismo y proporción sexual de Telenomus remus (Hymenoptera: Scelionidae) con relación al cogollero del maíz. Bioagro 12: 47-54.

Morales, J.; J. S. Gallardo; C. Vásquez \& Y. Ríos. 2001. Respuesta funcional de Telenomus remus (Hymenoptera: Scelionidae) a los huevos de Spodoptera frugiperda (Lepidoptera: Noctuidae). Bioagro 13: 49-55.

Reay-Jones, F. P. F; J. Rochat; R. Goebel \& E. Tabone. 2006. Functional response of Trichogramma chilonis to Galleria mellonella and Chilo sacchariphagus eggs. Entomologia Experimentalis et Applicata 118: 229-236.

Rogers, D. 1972. Random Search and Insect Populations Models. Journal of Animal Ecology 41: 369-383.

SAS Institute. 2004. SAS/STAT user's guide. Release 9.1 ed. SAS Institute, Cary, NC.

Schwartz, A. \& D. Gerling. 1974. Adult biology of Telenomus remus (Hymenoptera: Scelionidae) under laboratory conditions. Entomophaga 19: 482-492.

Tillman, P. G. 1996. Functional response of Microplitis croceipes and Cardiochiles nigriceps (Hymenoptera: Braconidae) to variation in density of Tobacco Budworm (Lepidoptera: Noctuidae). Biological Control 25: 254-528.

Van Alphen, J. J. M. \& M. Jervis 1996. Foraging behavior. In: Jervis M. \& N. Kidd (eds.). Insect natural enemies. New York, Chapman and Hall, $491 \mathrm{p}$.

Wang, B. \& D. N. Ferro 1998. Functional response of Trichogramma ostriniae (Hymenoptera: Trichogrammatidae) to Ostrinia nubilalis (Lepidoptera: Pyralidae) under laboratory and field conditions. Environmental Entomology 27: 752-758.

Wojcik, B.; W. H. Whitcomb \& D. H. Habech. 1976. Host range testing of Telenomus remus (Hymenoptera: Scelionidae). Florida Entomologist 59: 195-198.
Received 07/04/2009; accepted 21/10/2010

Editor: Daniel Ricardo Sosa-Gomez 